\title{
Closing the Gender Pay Gap in the EU
}

One of the most common inserts in EU policy documents is a statement that efforts should be made to close the gender pay gap. The problem is that the EU appears to have little clue how to bring that about and ignores the fact that much of its policy advice may have the opposite effect. This situation arises in my view from five separate but sometimes interrelated characteristics of its policy approach.

The first problematic characteristic is the focus on gaps, which generates at least three different concerns. First, there is the troubling fact that the recent narrowing of the aggregate pay gap is due to falls in men's wages and not improvements in women's earnings. Second, there is the problem of whether to use the raw gender pay gap or adjust it for differences in either the characteristics of men and women or of their jobs. The problem with the adjusted gap is not only that there are many ways to do the adjusting but also that "the 'explained' art of the gender pay gap is also likely to reflect 'discriminatory' social norms or (indirect) 'discrimination' related in particular to education and occupational choice".' So, like the EU, I prefer to use the unadjusted gap but in tandem with the total earnings gap, which allows us to identify countries that have achieved small gender pay gaps - for example Italy - but only because of low employment rates, particularly for lower-skilled women. However, there is no universal trade-off between pay gaps and employment rates, as the Nordic countries have demonstrated with their below average pay gaps and above average employment rates. The third and main concern with the EU's focus on gaps is when it is extended to measuring gaps within sectors and organisations, as if reducing gaps to zero within subparts of the economy would necessarily generate gender equality. It would be perfectly possible to imagine a scenario where there are zero gender gaps within organisations but a high aggregate gender pay gap, with more women being concentrated in lower paying organisations than men. Monitoring gender pay gaps within companies - as the EU is now proposing in its latest recommendation on equal pay - should make for greater transparency in pay setting and thus provide women with more ammunition to bargain for better pay. This development is to be welcomed, but action at the organisational level is unlikely to provide the main route to gender equality.

The second problem with the EU's gender pay gap policy is that the EU has no positon on the overall distribution of pay. The truth is that gender pay equality is much easier to achieve in contexts where pay inequality - between and within organisations - is low. While actions can be taken to reduce the tendency for women to be located towards the bottom of the pay hierarchy, reducing the actual wage penalty for being located near the bottom of the wage structure may be both the simplest and the most egalitarian way to make progress toward gender equality. ${ }^{2} \mathrm{EU}$ policy, if it is serious about closing the gender pay gap, needs to take a position on general wage inequality in the member states.

This brings me to my third and fourth problems, which involve two specific elements of current EU policies that may have negative impacts on the gender pay gap. These are particularly evident in the policies imposed by the troika, where the EU's real policy stance may be revealed. The first element is the approach to labour market regulation, including minimum wages. Women and young people are known to be the main groups

1 European Commission: Employment in Europe, Luxembourg 2001, p. 38.

2 F.D. Blau, L.M. Kahn: The Gender Earnings Gap: Learning from International Comparisons, in: American Economic Review, Vol. 82, No. 2, 1992, pp. 533-538; C. Juhn, K.M. Murphy, B. Pierce: Wage Inequality and the Rise in Returns to Skill, in: Journal of Political Economy, Vol. 101, No. 3, 1993, pp. 410-442; OECD: Employment Outlook, Paris 2002. 
directly affected by minimum wages, ${ }^{3}$ yet recommendations to cut minimum wages, as in Greece, or to moderate them are not assessed for their effect on the gender pay gap. In the UK, around 40 per cent of female part-time workers on adult rates in the private sector are paid within 11 per cent of the national minimum wage. This compares to less than 10 per cent of male full-time employees. Keeping minimum wages low in the UK would be unlikely to promote gender equity. The same applies to policies which aim to narrow the coverage of collective agreements, for example by limiting legal extensions in Portugal or prioritising firm- over sector-level agreements and allowing collective agreements to expire when no new agreement is signed, as in Spain. If women are employed in the weakly organised sectors and companies, the narrowing of collective bargaining coverage is unlikely to be positive for gender equality. ${ }^{4}$

Another questionable policy is the support for wage freezes and wage cuts in the public sector or, even more problematic, outsourcing to low-paying private sector organisations. These policies are mainly driven by fiscal consolidation but are often justified by reference to pay premiums in the public sector. However, higher pay may reflect higher qualifications among public sector workers or the very low pay for women in private sector organisations, which may be discriminatory. Policies to cut public sector wages have certainly not been subject to a gender audit. Three-fifths of all higher educated women in Europe in the labour market work in public services, compared to 30 per cent of higher educated men, so any policy to significantly cut public sector wages is likely to widen the gender pay gap, particularly for higher qualified workers. ${ }^{5}$

The final problem is that EU policy lacks any analysis of the different problems in member states. In some it is lower-skilled women who suffer from low minimum wages and limited opportunities for progress, while in others gender inequality may be more concentrated among the higher educated. Low pay for part-time work is a particular problem in the UK, where EU estimates show women part-timers earn only 68 per cent of fulltime female median earnings. This compares to 87 per cent in Germany (though those in so-called mini-jobs are likely to be much lower paid) and even higher ratios in the Netherlands (91 per cent) and Sweden (93 per cent). ${ }^{6}$ All four member states have high part-time employment shares, but the higher ratios reflect both higher minimum floors and more opportunities for part-time work through the job structure. One size certainly does not fit all, either by member state or by group of women. This means, for example, that policies for flexible working, considered essential to promote gender equality, could lead to the widening of the gender pay gap in some contexts if the outcome was, for example, growth in low-paid part-time work.

In short, progress on gender pay equality is likely to depend on general wage trends as well as on developing specific gender equality policies. The EU in the 1990s embraced the notion of gender mainstreaming of all policies, a principle it now seems to have forgotten in its promotion of labour market deregulation and wage cuts for public sector workers.

Jill Rubery, Manchester Business School, UK.
3 J. Rubery, D. Grimshaw: Gender and the minimum wage, in: S. Lee, D. McCann (eds.): Regulating for Decent Work, Basingstoke and Geneva 2011, ILO Publications.

4 For trends in collective bargaining coverage, see ETUI: Benchmarking Europe 2015, Brussels 2015.

5 J. Rubery: Austerity, the Public Sector and the Threat to Gender Equality, Geary Lecture 2014, in: The Economic and Social Review, Vol. 46, No. 1, 2015.

6 Eurostat data base Structure of Earnings Survey 2010. 